\title{
A STUDY ON PROPERTIES OF CONCRETE USING POND ASH AS PARTIAL REPLACEMENT OF CEMENT
}

\author{
K. M. Bagwan ${ }^{1}$, S. S. Kulkarni ${ }^{2}$ \\ ${ }^{I}$ Research Scholar, Shivaji University, Kolhapur, Maharashtra, India \\ ${ }^{2}$ Professor and Director, KES, Rajarambapu Institute of Technology, Sakharale, Islampur, Maharashtra, India
}

\begin{abstract}
This paper presents the experimental investigation carried out to study use of pond ash in concrete. Now a day it is important to think about effective utilization of pond ash to preserve natural resources and to have sustainable development. The concrete was prepared with different percentage of pond ash $(15,25,35,45$ and $55 \%)$ and it was tested at different ages (3,7,28,56,90, and 180 days). Results of pond ash concrete were compared with control concrete. For all proportions slump in a range of 100-120 mm was maintained. A property of pond ash concrete in fresh state and hardened state was tested. IST and FST of pond ash concrete goes on increasing as replacement level of pond ash with cement increases this is because of less content of cement. Also it is found that rate of increase of compressive strength at early ages mainly 3,7 and 28 days was low and during later age this rate was faster. This shows that later age strength of pond ash concrete is very good and has a scope to use in concrete which are of great importance in the present context of sustainability in the construction field.
\end{abstract}

Keywords: Pond ash, Compressive strength, Slump, and Fly ash.

\section{INTRODUCTION}

Lot of research has been carried out to use alternative material in concrete so as to satisfy various properties of concrete. Pond ash is one such alternative material which can be effectively used to replace the natural material. When coal is burned mainly fly ash and bottom ash is produced. The fly ash is collected by Electrostatic precipitator process. The ash which is fall at the bottom of boiler is mixed with water, and then it is carried away from plant through pipes and finally dumped on open land. After evaporation whatever ash remains is called pond ash. The use of pond ash limited by technical and other concern, in structural concrete but it can be conveniently used in geotechnical and highway constructions, mass concrete construction, earth fill, encouraging the use of huge amount of pond ash generated from thermal power station. The power generation in India is likely to go up from $1,12,090 \mathrm{MW}$ to $2,12,000$ MW in the year 2012 [1]. Every year about 65 to 75 million tonnes of ash continue to remain unutilized and dumped in ash ponds and the quantity of ash in ash ponds has increased from about 450 million tonnes in 1999-2000 to more than 900 million tonnes in 2005-2006 [17]. For disposal of this ash requires huge valuable land which may be agricultural or forest. Dr. Yashpal Singh (2011) [12] state that by the year 2015, the disposal of coal ash would require 1000 square $\mathrm{km}$. area or one meter square of land per person in India.

The disposal of Pond ash is a big challenge to all as concerning to their quantity which is increasing day by day. Hence worldwide investigation was performed to find alternative use of this waste material and its use in concrete as a partial replacement of cement is one of the effective methods of utilization. The possibility of utilization of thermal power plant byproduct i.e. pond ash as replacement to cement in concrete is taken into consideration.

\section{RESEARCH SIGNIFICANCE}

The work carried out by Nader Ghafoori and Yuzheng Cai (1998) [20] shows that inclusion of bottom ash increases the demand for mixing water in obtaining the required workability. In this study lignite based bottom ash used as a fine aggregate in structural grade concrete. The work of Glicerio Triches et al. [13] presents a laboratory research of RCC mixtures with addition of bottom ash for composite pavements. The results revealed an increase in flexural strength levels at increasing levels of fine aggregate replacement by bottom ash. This study also indicates that the addition of bottom ash in RCC mixtures might lead to lower cement contents as well as to a less demand of fine aggregates. The investigations reported by Bapat et al. (2006) [15] shows that the lagoon ash used to make concrete with low strength. The development of early strength $(1,3$ days) was found low. The setting time of concrete with lagoon ash was more in comparison to that for concrete with fly ash. The study of Bharati et al. (2011) [3] confirms that pond ash can be used as a material for roads and embankment works and also replace a part of cement and sand in concrete pavements thus making them more economical. According to Chai Jaturapitakkul and Raungrut Cheerarot (2003) [11], pastes with original or ground bottom ash replacing Portland cement type I between 10 to $30 \%$ resulted in longer initial setting time of about 9-23 minutes, depending on the fineness of the ashes, compared to the setting time of the cement paste. Haldun Kurama, Mine Kaya (2008) [14] found that addition of bottom ash up to $10 \%$ as a replacement material for Portland cement could improve the mechanical properties of concrete and thus could be used in the concrete industry. Sungmin Yoon et al. (2009) [23] shows that embankment built with as ash mixtures (60:40 by weight of fly ash:bottom ash) and 
monitored for a period of 1 year from start of construction. By monitoring data from vertical and horizontal inclinometers and settlement plates indicates that the ash mixture investigated can be acceptable embankment construction material. The research reported by Yogesh Aggarwal, Rafat Siddique (2014) [26] shows that the greatest increase in compressive, splitting tensile strength, and flexural strength compared to that of the conventional concrete was achieved by substituting $30 \%$ of the natural fine aggregate with industrial by-product aggregate (bottom ash and waste foundry sand).

By studying all above literature it is known that the generation of coal ash is a very large in quantity which will be hazardous for the environment and for human if not utilized properly. Also it indicates that there is scope to utilize pond ash in making concrete and achieving sustainability in the construction field.

\section{MATERIALS}

\subsection{Significance}

The investigation reported in this paper was undertaken to develop concrete using pond ash collected from ash ponds of Tukum, Chandrapur Super Thermal power generating station in Maharashtra state, India.

\subsection{Materials}

The materials used were as follows.

\subsubsection{Cement}

The Portland Cement (PC) of 53 grade was used. Cement used conforms to IS 12269:1987 (Bureau of Indian Standards 1987) specifications. The physical and chemical properties of the PC are given in Table 1.

\subsubsection{Ash}

The pond ash used in present study has been collected from different locations of Chandrapur Thermal Power Station, Tukum, Chandrapur, Maharashtra, India. Fig. 1(a) and (b) shows dumped pond ash at Chandrapur Super Thermal Power (CSTP) Station and disposal of pond ash to open land through pipes. Pond ash was used on as-received basis. The physical and chemical properties of pond ash collected from above source are given in Table 2

\subsubsection{Aggregate}

Naturally available sand was used as fine aggregate. Before using in concrete, sand is properly washed and classified. The crushed basalt obtained from a quarry was used as coarse aggregate. This aggregate was obtained in two sizes namely, $10 \mathrm{~mm}$ and $20 \mathrm{~mm}$ and mixed to a specific grading. Table 3 gives the grading and the properties of the coarse and fine aggregate.

Table 1 Physical and Chemical properties of Portland Cement

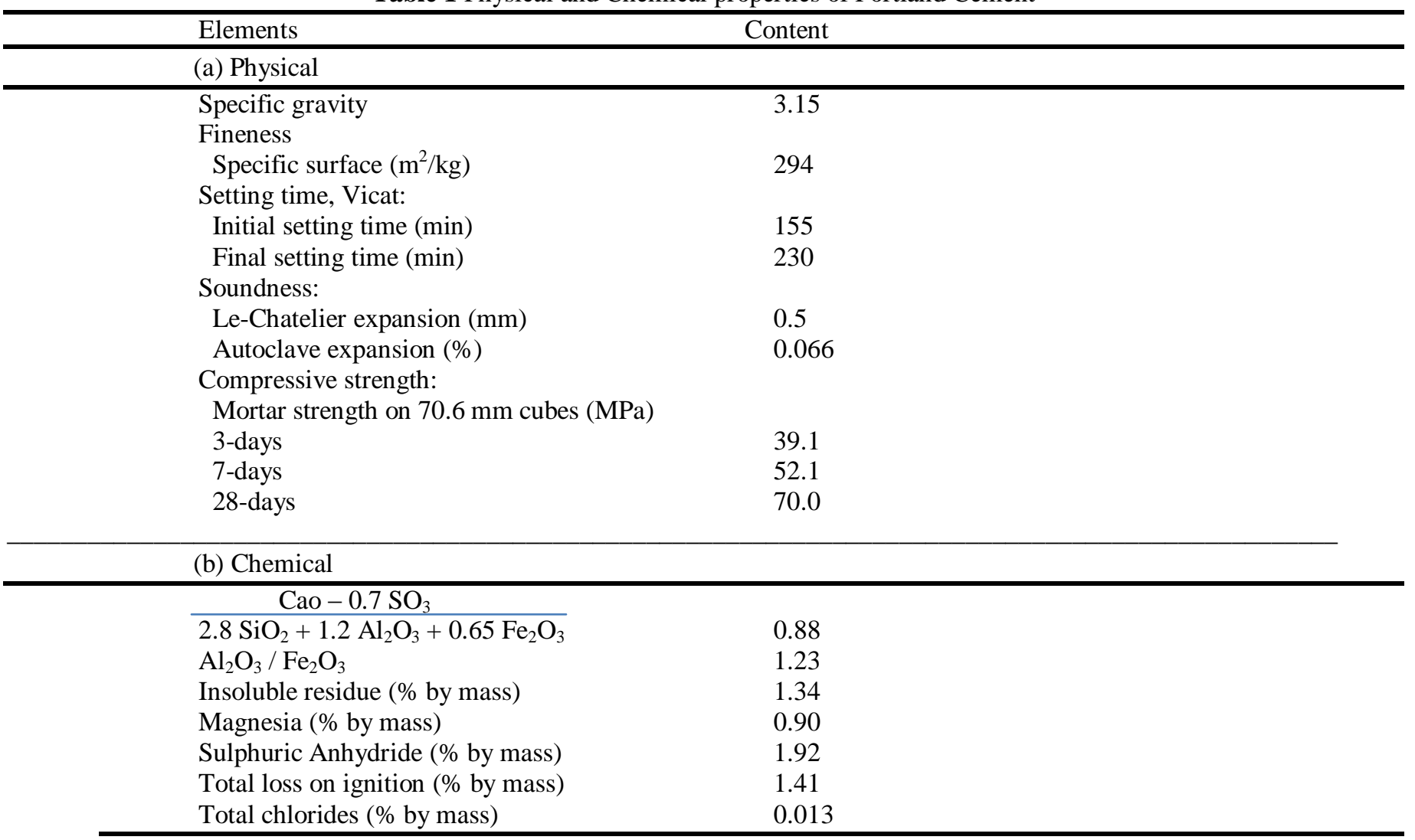


Table 2 Physical and Chemical properties of Pond ash

\begin{tabular}{lll}
\hline Elements & Content & ${ }^{\mathrm{a}}$ IS Requirement \\
\hline (a) Physical & & - \\
\hline Fineness-passing $45 \mu \mathrm{m}(\%)$ & 61.05 & - \\
Specific gravity & 2.02 & \\
\hline (b) Chemical & & Minimum 35.00 \\
\hline Silicon dioxide, $\mathrm{SiO}_{2}$ & 60.60 & \\
Aluminum oxide, $\mathrm{Al}_{2} \mathrm{O}_{3}+$ & & \\
Ferric oxide, $\mathrm{Fe}_{2} \mathrm{O}_{3}$ & 31.29 & Minimum 70.00 \\
$\left(\mathrm{SiO}_{2}+\mathrm{Al}_{2} \mathrm{O}_{3}+\mathrm{Fe}_{2} \mathrm{O}_{3}\right)$ & 91.89 & \\
$\mathrm{Calcium} O \mathrm{Oxide}, \mathrm{CaO}$ & 1.86 & Maximum 5.00 \\
Magnesium Oxide, $\mathrm{MgO}$ & 0.58 & Maximum 2.75 \\
Sulfur Tri Oxide, $\mathrm{SO}_{3}$ & 0.54 & Maximum 1.50 \\
Sodium oxide, $\mathrm{Na}_{2} \mathrm{O}$ & 0.21 & Maximum 12.00 \\
Loss on ignition & 2.2 &
\end{tabular}

${ }^{a}$ IS 3812:1981 = Specification for fly ash for use as Pozzolana and admixture (Bureau of Indian Standards 1981) and IS 1727:1967 = Methods of test for pozzolanic materials (Bureau of Indian Standards 1967).

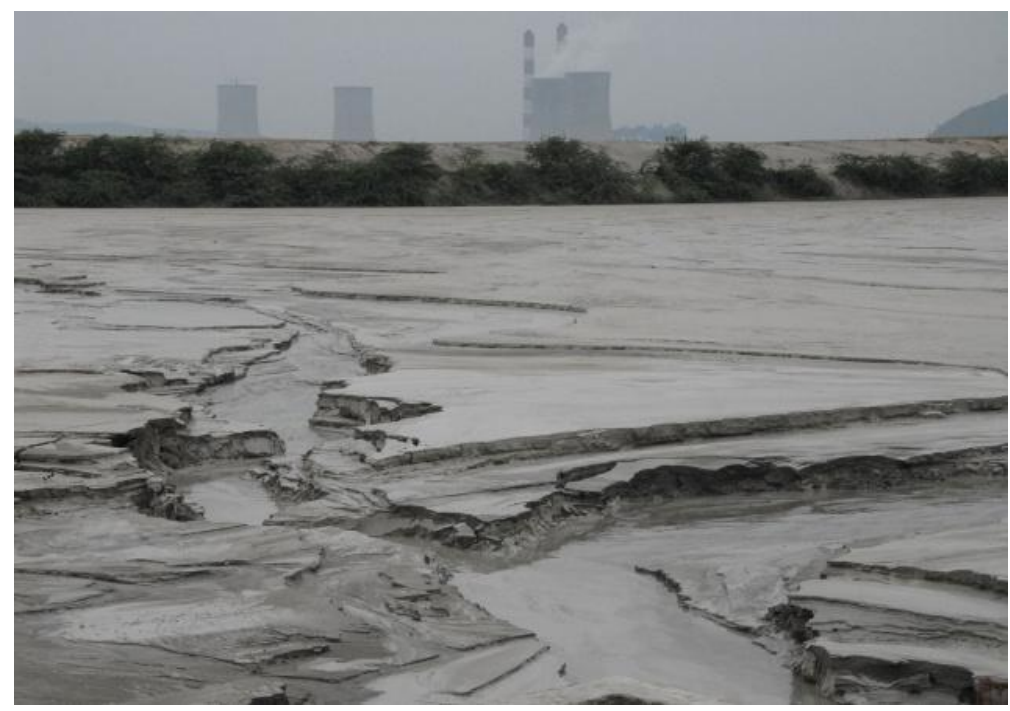

a)

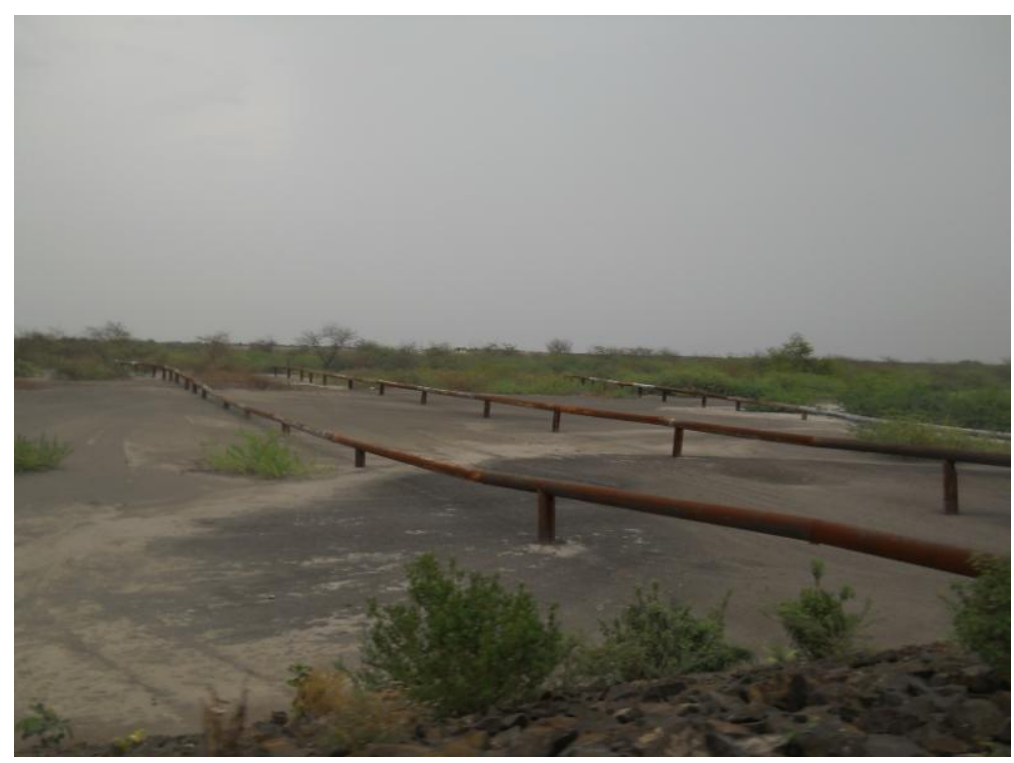

b)

Fig -1: a) Dumped Pond ash b) Disposal of pond ash through pipe 
Table 3 Grading and Properties of Coarse and Fine aggregate

\begin{tabular}{|c|c|c|c|}
\hline \multicolumn{2}{|c|}{$\begin{array}{l}\text { Coarse Aggregate } \\
\text { (crushed basalt) }\end{array}$} & \multicolumn{2}{|c|}{$\begin{array}{l}\text { Fine Aggregate } \\
\text { (natural sand) }\end{array}$} \\
\hline Sieve size $(\mathrm{mm})$ & $\begin{array}{l}\text { Cumulative } \\
\text { percent retained }\end{array}$ & Sieve size $(\mathrm{mm})$ & $\begin{array}{l}\text { Cumulative } \\
\text { percent retained }\end{array}$ \\
\hline 80 & 0 & 4.75 & 12.5 \\
\hline 40 & 0 & 2.36 & 25.6 \\
\hline 20 & 0 & 1.18 & 53 \\
\hline 10 & 9.5 & 0.6 & 81 \\
\hline 4.75 & 93.95 & 0.3 & 97.8 \\
\hline 2.36 & 98.95 & 0.15 & 99.2 \\
\hline 1.18 & 100.0 & & \\
\hline Fineness Modulus & 6.018 & 3.59 & \\
\hline Specific gravity & 2.88 & 2.66 & \\
\hline Bulk density & $1765.05 \mathrm{~kg} / \mathrm{m} 3$ & 1984.37 & \\
\hline Water absorption & $1.67 \%$ & - & \\
\hline Surface moisture & - & - & \\
\hline
\end{tabular}

\subsubsection{Super Plasticizer}

High Range Water Reducing Admixture was used. A commercially available super plasticizer - ConplastSP430SRV complies with the requirement of ASTM C 494-80 as a Type G Retarding was used.

\section{CONCRETE MIX PROPORTIONS AND MIX DESIGN}

Mix was carried out as per stipulations laid down in IS 456:2000 and IS 10262:2009 (Bureau of Indian Standards). Concrete mix design is the process of obtaining various ingredients of concrete such as cement, aggregate, water and admixtures, if any, in the most optimal manner. The main intention is to produce a concrete at minimal cost having specified properties in fresh as well as in hardened state.

In present study concrete mix was designed for M25 grade concrete. For selection of control concrete, the trial mixes was carried out and finally mix with 0.49 water cement ratio was finalized. Water absorption and surface moisture of coarse and fine aggregate were taken into account during mix design. Desired slump was maintained between 100-120 mm for all mixtures. For getting desired slump super plasticizer was added if required.

Concrete was prepared by using laboratory pan mixer of one bag capacity. The concrete mixtures were prepared replacing cement in different proportions with pond ash. The replacement level of pond ash with cement was started from $15 \%, 25 \%, 35 \%, 45 \%$, and $55 \%$. Table 4 show concrete mix proportions used in present study.

Table 4 Mix Proportions of concrete

\begin{tabular}{|c|c|c|c|c|c|c|c|}
\hline \multirow[b]{3}{*}{ Mix } & \multirow[b]{3}{*}{${ }^{\$} \mathrm{w} / \mathrm{b}$} & \multirow[b]{3}{*}{ Water } & \multicolumn{4}{|c|}{ Batch quantity in $\mathrm{kg} / \mathrm{m}^{3}$} & \multirow[b]{3}{*}{ CA } \\
\hline & & & \multicolumn{3}{|c|}{ Pond ash } & \multirow[b]{2}{*}{ FA } & \\
\hline & & & Cement & Percentage & $\overline{\text { Quantity }}$ & & \\
\hline Control & 0.49 & 181 & 368 & - & - & 645 & 1271 \\
\hline M1 (15\%) & 0.49 & 181 & 313 & 15 & 55 & 645 & 1271 \\
\hline M2 (25\%) & 0.49 & 181 & 276 & 25 & 92 & 645 & 1271 \\
\hline M3 $(35 \%)$ & 0.49 & 181 & 239 & 35 & 129 & 645 & 1271 \\
\hline M4 (45\%) & 0.49 & 181 & 202 & 45 & 166 & 645 & 1271 \\
\hline M5 (55\%) & 0.49 & 181 & 166 & 55 & 202 & 645 & 1271 \\
\hline
\end{tabular}

${ }^{\$} \mathrm{w} / \mathrm{b}=$ water/binder ratio, i.e. water $/($ cement + pond ash $), \mathrm{FA}=$ Fine aggregate, $\mathrm{CA}=$ Coarse aggregate

Note: At $45 \%$ and $55 \%$ replacement level of pond ash, super plasticizer dose of $0.1 \%$ of cement weight was required to maintain desired workability (i.e. 100-120mm).

Procedure given in IS 10262:2009 mix design code were followed. Initially lumps if any present in pond ash were broken and required quantity of cement and pond ash was mixed with half the quantity of required coarse and fine aggregate till uniform color is obtained. Then $3 / 4$ quantities of water and remaining aggregate were mixed. After getting homogeneous mix remaining water and super plasticizer if required was added. The total mixing procedure was completed within 4-5 minutes. 


\subsection{Checking Properties Of Concrete}

\subsubsection{In Fresh State}

The various properties of concrete in fresh state such as slump, IST and FST of concrete and density were observed and noted.

\section{Initial and Final Setting Time (IST and FST) of Concrete}

IST and FST of concrete provide guidance to site engineer regarding removal of formwork and permissible time lapse between placements of successive layers of concrete. The test is conducted as per IS 8142:1976 (Bureau of Indian

Standards) and ASTM C - 403. Table 5 shows IST and FST of pond ash concrete for different percentage replacement of pond ash by cement. The setting time of pond ash concrete is more than control concrete. This is in line with the investigation reported by Bapat et al. (2006).

Table 5 IST and FST of pond ash concrete

\begin{tabular}{lll}
\hline \% replacement & $\begin{array}{l}\text { IST } \\
\text { (minutes) }\end{array}$ & $\begin{array}{l}\text { FST } \\
\text { (minutes) }\end{array}$ \\
\hline 15 & 300 & 445 \\
25 & 300 & 465 \\
35 & 360 & 520 \\
45 & 390 & 600 \\
55 & 390 & 630 \\
\hline
\end{tabular}

\subsubsection{In Hardened State}

Concrete cubes of size $15 \times 15 \times 15$ cm (IS 516:1959, Reaffirmed in 1999) (Bureau of Indian Standards 1999) were casted and average compressive strength of cubes was determined. Initially molds were filled with concrete in three layers with sufficient compaction. Then concrete cubes were placed on laboratory vibrating table for proper vibration and expulsion of air. After vibration, molds were covered with jute bags for 24 hours. The cubes were demolded after 24 hours and placed in water tanks for curing at temperature $27 \pm 2^{\circ} \mathrm{C}$ (IS 516:1959) for 14 days (IS 456:2000) and then they were air dried. A minimum of three cubes were tested at a given test age. Figs. 2(a)-(b) shows pond ash concrete cube test using digital compressive testing machine and IST, FST of concrete cube test. Table 6. shows compressive strength of pond ash concrete.

Table 6 Compressive strength of pond ash concrete

\begin{tabular}{|c|c|c|c|c|c|c|c|c|c|}
\hline \multirow[b]{2}{*}{$\begin{array}{l}\text { Sr Mix } \\
\text { No }\end{array}$} & \multirow[b]{2}{*}{$\begin{array}{l}\text { \% Repl. } \\
\text { of PA }\end{array}$} & \multirow[b]{2}{*}{$\begin{array}{l}\text { Slump } \\
(\mathrm{mm})\end{array}$} & \multirow[b]{2}{*}{$\begin{array}{l}\text { Density } \\
\left(\mathrm{kg} / \mathrm{m}^{3}\right)\end{array}$} & \multicolumn{6}{|c|}{ Compressive strength (MPa) at various days } \\
\hline & & & & 3 & 7 & 28 & 56 & 90 & 180 \\
\hline 1 Contro & $81-$ & 120 & 2460 & $\begin{array}{l}15 \\
(46.8)\end{array}$ & $\begin{array}{l}24 \\
(75)\end{array}$ & $\begin{array}{l}32 \\
(100)\end{array}$ & $\begin{array}{l}38 \\
(118.7)\end{array}$ & $\begin{array}{l}44 \\
(137.5)\end{array}$ & $\begin{array}{c}46 \\
(143.7)\end{array}$ \\
\hline 2 M1 & 15 & 116 & 2391 & $\begin{array}{l}15 \\
(53.6)\end{array}$ & $\begin{array}{l}20.1 \\
(71.8)\end{array}$ & $\begin{array}{l}28 \\
(100)\end{array}$ & $\begin{array}{l}35.3 \\
(126.1)\end{array}$ & $\begin{array}{l}40.5 \\
(144.6)\end{array}$ & $\begin{array}{r}42.2 \\
(150.7)\end{array}$ \\
\hline 3 M2 & 25 & 114 & 2380 & $\begin{array}{l}13.6 \\
(51.9)\end{array}$ & $\begin{array}{l}17.8 \\
(67.9)\end{array}$ & $\begin{array}{l}26.2 \\
(100)\end{array}$ & $\begin{array}{l}33 \\
(125.9)\end{array}$ & $\begin{array}{l}38 \\
(145.0)\end{array}$ & $\begin{array}{c}40 \\
(152.7)\end{array}$ \\
\hline $4 \mathrm{M} 3$ & 35 & 114 & 2375 & $\begin{array}{l}11.2 \\
(47.7)\end{array}$ & $\begin{array}{l}14.3 \\
(60.8)\end{array}$ & $\begin{array}{l}23.5 \\
(100)\end{array}$ & $\begin{array}{l}30.8 \\
(131.1)\end{array}$ & $\begin{array}{l}36.6 \\
(155.7)\end{array}$ & $\begin{array}{r}37.3 \\
(158.7)\end{array}$ \\
\hline 5 M4 & 45 & 118\# & 2360 & $\begin{array}{l}6.3 \\
(27.6)\end{array}$ & $\begin{array}{l}11.6 \\
(50.8)\end{array}$ & $\begin{array}{l}22.8 \\
(100)\end{array}$ & $\begin{array}{l}28.5 \\
(125)\end{array}$ & $\begin{array}{l}32.8 \\
(143.8)\end{array}$ & $\begin{array}{r}36.4 \\
(159.6)\end{array}$ \\
\hline 6 M5 & 55 & 119\# & 2355 & $\begin{array}{l}6 \\
(34.3)\end{array}$ & $\begin{array}{l}9.7 \\
(55.4)\end{array}$ & $\begin{array}{l}17.5 \\
(100)\end{array}$ & $\begin{array}{l}24.5 \\
(140)\end{array}$ & $\begin{array}{l}29.4 \\
(168.0)\end{array}$ & $\begin{array}{c}34 \\
(194.3)\end{array}$ \\
\hline
\end{tabular}

Repl = Replacement; PA - pond ash, \# - 0.1\% Super plasticizer used

* Figure in bracket indicate percentage rise in compressive strength in relation to 28 days strength 


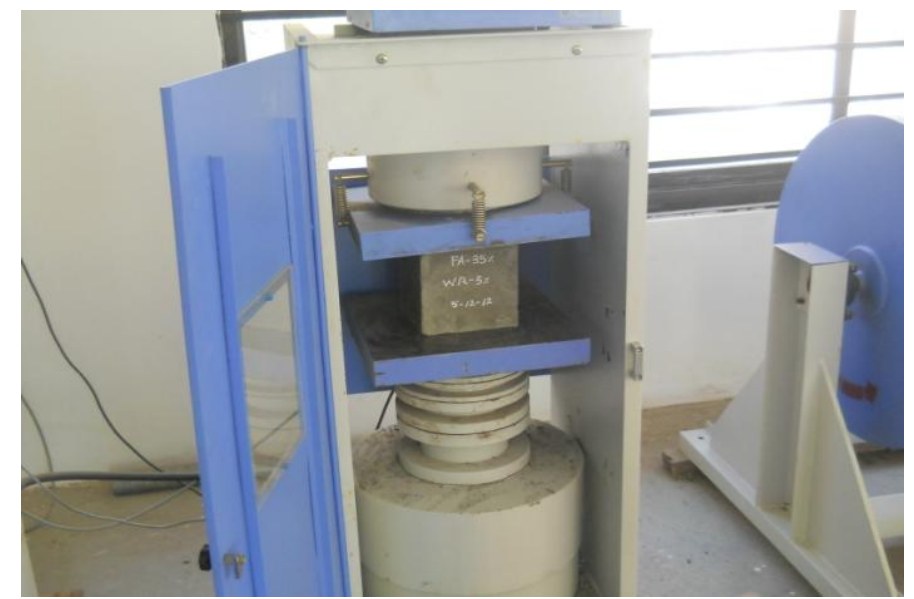

(a)

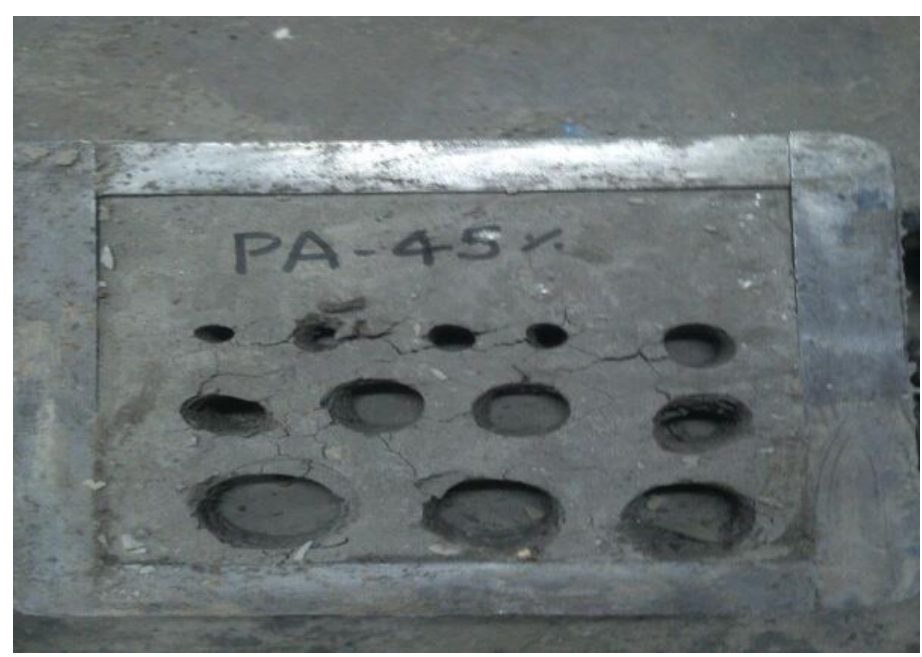

(b)

Fig. 2 (a) Pond ash concrete cube test (b) IST and FST of pond ash concrete

\section{SUMMARY AND CONCLUSIONS}

From the preceding discussions, the following conclusions can be summarized.

- It was observed from graph given in Fig. 3 that rate of increase of compressive strength at early ages mainly 3,7 and 28 days was low but during later age this rate was faster which indicates that pond ash concrete has good later age strength.

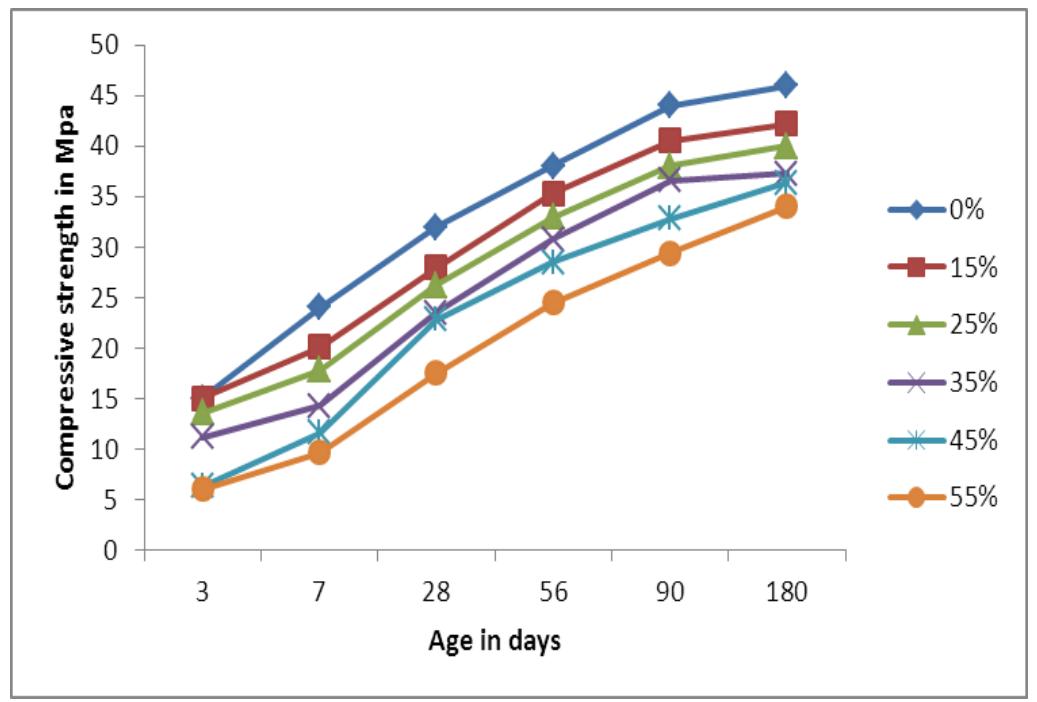

Fig 3: Compressive strength of pond ash concrete at different ages and for different percentage replacement 
The rate of chemical reaction of pond ash is slow at early ages with calcium hydroxide which is liberated during hydration of cement but when rate of reaction increases it forms stable calcium silicate and aluminate hydrates. This chemical reaction improves strength and durability of concrete. The results of compressive strength obtained by authors Bharati (2012), Bapat (2006), Bhangale (2013), Chai (2003) verifies with present investigations made.

- Table 6 shows compressive strength of pond ash concrete cubes with different percentage of pond ash, number in bracket shows the percentage compressive strength of cube in comparison to 28 days strength. It is also known that strength of pond ash concrete goes on decreasing as percentage of pond ash increases; this is mainly due to less availability of binding material i.e. cement and higher un-burnt carbon contents of pond ash.

- In present study workability of concrete in term of slump was maintained between 100- $120 \mathrm{~mm}$. For first three replacement level of pond ash namely $15 \%, 25 \%$ and $35 \%$ the workability is obtained within the range. But at $45 \%$ and $55 \%$ replacement level, workability of concrete was less than $100 \mathrm{~mm}$ and hence super plasticizer dose was added. This phenomenon may be due to coarse nature of pond ash and more carbon content. The dose of super plasticizer was varied from $0.1 \%, 0.2 \%$, and $0.3 \%$ and finally an optimum dose of $0.1 \%$ was selected for getting desired workability.

- $\quad$ Specific gravity of pond ash is 2.02 which is less than general value of specific gravity of cement, this reduces density of concrete. Table 6 shows linear decrease in density of pond ash concrete. Fineness of pond ash passing through $45 \mu \mathrm{m}$ is $61.05 \%$ which indicates coarseness of pond ash.

- Initial and final setting time of pond ash concrete goes on increasing as replacement level of pond ash with cement increases. That is perhaps due to less content of cement.

The study carried out indicate that viability of using pond ash in making concrete which are of great importance in the present context of sustainability in the construction field.

\section{ACKNOWLEDGMENTS}

Authors would like to thanks to Director and Management of KES, Rajarambapu Institute of Technology, Sakharale, Prof. S. S. Sabnis, Chief Technology Officer, StrongGid Technologies, Pune and KJ College of Engineering and Management Research, Pune for their support and encouragement in research activities.

\section{REFERENCES}

[1]. Arumugam, K., Ilangovan. R., James Manohar D. (2011), "A study on characterization and use of pond ash as fine aggregate in concrete", International Journal of Civil and Structural Engineering, 2(2), 466-474.
[2]. Ashis Kumar Bera, Ambarish Ghosh, and Amalendu Ghosh (2007), "Compaction characteristics of pond ash", Journal of Materials in Civil Engineering, ASCE, 19(4), 349-357.

[3]. Bharathi Ganesh, H.Sharada Bai, R.Nagendra (2011), "Effective utilization of pond ash for sustainable construction - need of the hour", International Journal of Earth Sciences and Engineering, 4(6), 151-154.

[4]. Bureau of Indian Standards IS 516 (1959), Method of test for strength of concrete, New Delhi, India.

[5]. Bureau of Indian Standards IS 1727 (1967), Methods of test for pozzolanic materials, New Delhi, India.

[6]. Bureau of Indian Standards IS 2386 (Part IV) (1963), Methods of test for aggregates for concrete-Mechanical properties, New Delhi, India.

[7]. Bureau of Indian Standards IS 8142 (1976), Method of test for determining setting time of concrete by penetration resistance, New Delhi, India.

[8]. Bureau of Indian Standards IS 10262 (2009), Recommended guidelines for concrete mix design, New Delhi, India.

[9]. Bureau of Indian Standards IS 12269 (1987), Specification for 53 grade ordinary Portland cement, New Delhi, India.

[10]. Bureau of Indian Standards IS 456 (2000), Code of practice for plain and reinforced concrete (3rd revision), New Delhi, India.

[11]. Chai Jaturapitakkul and Raungrut Cheerarot (2003), "Development of bottom ash as pozzolanic material", Journal of Materials in Civil Engineering, ASCE, 15(1), 4853.

[12]. Dr. Yashpal Singh, "Fly ash utilization in India" posted by Dr. Yashpal Singh on Jan. $6^{\text {th }} 2011$, comments for fly ash utilization in India.

[13]. Glicerio Triches, Alexandre Jose da Silva, Roberto de Andrade Caldas Pinto, "Incorporating bottom ash in roller compacted concrete for composite pavements", Universidade Federal de Santa Catarina.

[14]. Haldun Kurama, Mine Kaya (2008), "Usage of coal combustion bottom ash in concrete mixture", Construction and Building Materials, Elsevier, 22, 1922-1928.

[15]. J. D. Bapat; S. S. Sabnis; C. V. Hazaree (2006), "Ecofriendly Concrete with High Volume of Lagoon Ash", Journal of Materials in Civil Engineering, ASCE, 15(1), 4853.

[16]. Maharashtra State Power Generation Co. Ltd., "Fly ash Utilization of MahaGenco TPS”, June 2010, 1-17.

[17]. Ministry of Environment and Forests (MoEF) Notification, New Delhi, $3^{\text {rd }}$ April, 2007, published in The Gazette of India: Extraordinary [Part II-Sec.3(ii)].

[18]. M. L. Gambhir (1992), Concrete Manual, Dhanpat Rai and Company Pvt. Ltd., New Delhi, India.

[19]. M. S. Shetty (2010), Concrete Technology, S. Chand and Company Ltd., New Delhi, India.

[20]. Nader Ghafoori and Yuzheng Cai (1998), "Laboratorymade roller compacted concretes containing dry bottom ash: Part I - Mechanical properties", ACI Material Journal, 95(2), 121-130. 
[21]. Nader Ghafoori and Yuzheng Cai (1998), "Laboratorymade roller compacted concretes containing dry bottom ash: Part II - Long term durability", ACI Material Journal, 95(3), 244-250.

[22]. State Environment Related issues Department of Forests, Ecology and Environment, Government of Karnataka, "ENVIS Newsletter", Vol.2 No. 6, January 2007, $1-5$.

[23]. Sungmin Yoon; Umashankar Balunaini; Irem Z. Yildirim; Monica Prezzi; and Nayyer Z. Siddiki (2009), "Construction of an embankment with a fly and bottom ash mixture: Field performance study", Journal of Materials in Civil Engineering, ASCE, 21(6), 271-278.

[24]. Report of Centre for fly ash research and management (C-FARM) web link, www.c-farm.org.

[25]. Tarun R. Naik (2008), "Sustainability of Concrete Construction", Practice periodical on structural design and construction, ASCE, 98-103.

[26]. Yogesh Aggarwal, Rafat Siddique (2014), "Microstructure and properties of concrete using bottom ash and waste foundry sand as partial replacement of fine aggregates", Construction and Building Materials, Elsevier, 54, 210-223.

\section{BIOGRAPHIES}

K M Bagwan, Research Scholar, Shivaji University, Kolhapur, Maharashtra, India

Dr. Mrs. S S Kulkarni, PhD, M E Civil Professor and Director, KES, Rajarambapu Institute of Technology, Sakharale, Islampur. She has 25 years of teaching experience. She has published more than 36 research papers in various National and International journals and Conferences. 